\title{
Korean Wave (Hallyu) dan Persepsi Kaum Muda di Indonesia: Peran Media dan Diplomasi Publik Korea Selatan
}

\author{
Jusmalia Oktaviani \\ Jurusan Ilmu Hubungan Internasional, Universitas Jenderal Achmad Yani \\ Email: jusmalia.oktaviani@lecture.unjani.ac.id \\ Teguh Puja Pramadya \\ Program Studi Bahasa Inggris, Universitas Widyatama \\ Email: teguh.puja@widyatama.ac.id
}

\begin{abstract}
Abstrak
Budaya populer Gelombang Korea (Korean Wave/Hallyu) dari Korea Selatan telah menyebar hampir ke seluruh dunia, termasuk Indonesia. Produk budaya Korea Selatan seperti musik, film, tarian, drama televisi, hingga produk budaya lain seperti bahasa dan kuliner, banyak digemari oleh masyarakat Indonesia, terutama generasi muda. Sebagai dampak globalisasi yang menyebarkan Gelombang Korea, kaum muda tentu saja mendapatkan porsi yang besar, karena mereka menjadi penikmat semua aspek budaya popular tersebut. Dalam kurun waktu beberapa tahun terakhir, penelitian yang membahas mengenai Korea Selatan, terutama mengenai Gelombang Korea, menjadi salah satu topik paling populer. Oleh karena itu, peneliti mengajukan pertanyaan penelitian: bagaimana pengaruh Korean Wave (Hallyu) terhadap persepsi kaum muda mengenai Korea Selatan di Indonesia, khususnya pada Mahasiswa Hubungan Internasional FISIP Unjani? Penelitian ini menggunakan metode penelitian kualitatif, dengan teknik pengumpulan data menggunakan data focus group discussion, observasi, serta teknik dokumentasi. Hasil penelitian menyatakan bahwa Gelombang Korea memang memiliki pengaruh yang cukup besar pada mahasiswa, sehingga para mahasiswa ini tertarik untuk mempelajari aspek-aspek budaya yang berasal dari Korea Selatan, diikuti dengan peran media yang masif dan signifikan, membawa aspek-aspek tersebut sebagai pilihan hiburan bagi para kaum muda.
\end{abstract}

Kata kunci: budaya pop, mahasiswa Indonesia, Korean Wave

Abstract

The South Korean popular culture known as the Korean Wave (Hallyu) has spread to almost every country globally, including Indonesia. South Korean cultural items, ranging from music, films, dances, and television dramas to language and cuisine, are common among Indonesians, especially the younger generation. As a result of globalization, which extends the Korean Wave, young people, who are connoisseurs of all facets of mainstream culture, receive a substantial portion. In recent years, research on South Korea, especially its Korean Wave, has become one of the most prominent topics. As a result, the researcher raises the following research question: How does the Korean Wave (Hallyu) affect youth perceptions of South Korea in Indonesia, especially among students of International Relations at the Faculty of Social and Political Sciences Unjani? This study employs observational analysis approaches, with data collected by focus group discussions, observation, and documentation techniques. According to the study's findings, the Korean Wave had a significant impact on students. These students became involved in researching cultural factors originating in South Korea, followed by the massive and considerable media coverage, bringing these aspects as entertainment options for young people.

Keywords: Indonesian students, Korean Wave, popular culture 


\section{PENDAHULUAN}

Gelombang Korea/ Korean Wave/ Hallyu merupakan fenomena global yang menjadi perhatian penstudi Hubungan Internasional saat ini. Gelombang Korea dimulai dari negara asalnya yakni Korea Selatan, yang kemudian menyebar ke seluruh dunia, dari Asia hingga ke Eropa dan Amerika. Adapun produk yang tersebar tersebut tak lain adalah berbagai produk budaya popular yang memang menyebar dengan cepat. Hanya dalam kurun waktu yang cukup singkat, yakni semenjak akhir tahun 1990an, Korea Selatan menjadi terkenal karena budaya popnya tersebut. Gelombang Korea ini pun menjangkau hampir semua produk budaya, baik berupa drama televisi, film, variety show, industri musik, yang kemudian merambah ke kegemaran masyarakat luar atas produk budaya lain seperti kuliner, busana, bahasa Korea, dan lain-lain (Jang dan Won, 2012).

Meningkatnya permintaan pasar atas produk budaya Korea Selatan ini dimanfaatkan dengan baik oleh Pemerintah Korea Selatan, yang mana Pemerintah Korea Selatan sangat mendukung tersebarnya Gelombang Korea ini. Bantuan pemerintah ini diberikan karena pemerintah juga menggunakan Gelombang Korea untuk memuluskan langkah diplomasi publik dan soft power Korea Selatan di mata negara lain. Hal ini dilakukan tentunya untuk memudahkan pencapaian kepentingan nasional Korea Selatan serta untuk peningkatan citra negara itu (Jang dan Won 2012; Pramadya, dan Jusmalia 2016).

Kesuksesan diplomasi budaya Korea Selatan ini pun berdampak positif kepada Korea Selatan terutama pada sektor ekonomi. Sementara itu, akibat popularitas industri film, drama, dan variety show, tempat-tempat yang menjadi lokasi syuting di Korea Selatan menjadi incaran para turis mancanegara. Korea Selatan yang tadinya tidak pernah menjadi tempat destinasi wisata, mendadak berubah menjadi tempat impian paling utama bagi pecinta budaya pop negara itu. Hampir semua aspek dalam kebudayaan Korea Selatan juga hadir di negara-negara lain, seperti restoran Korea, di Bandung ada Little Korea, dan lain sebagainya. Industri lain seperti kosmetik, busana, juga menjadi kiblat baru bagi perkembangan di bidang ini.

Sebagai dampak globalisasi yang menyebarkan Gelombang Korea, para mahasiswa Jurusan Hubungan Internasional FISIP Unjani pun tak luput dari pengaruh gelombang Korea ini. Banyak penelitian mengenai Korea Selatan, terutama mengenai Gelombang Korea. Sisi yang diangkat pun sangat beragam, mulai dari topik-topik terkait K-Pop, soft power, kebijakan pemerintah, dan berbagai sudut pandang penelitian lainnya.

Efek spillover pun berlanjut karena dengan meningkatnya citra Korea Selatan sebagai negara yang maju dan modern. Penelitian tentang Korea Selatan pun tidak berhenti pada industri hiburan, tapi juga pada aspek-aspek lain seperti ekonomi, pertahanan-keamanan, dan lain-lain. Hal inilah yang mendorong rasa ingin tahu peneliti untuk mengelaborasi lebih jauh dan lebih spesifik mengenai pengaruh Gelombang Korea bagi persepsi mahasiswa FISIP Unjani mengenai Korea Selatan, khususnya mahasiswa pada program studi Hubungan Internasional.

Oleh karenanya, penelitian ini berusaha menjawab pertanyaan penelitian sebagai berikut: bagaimana pengaruh Korean Wave (Hallyu) terhadap persepsi kaum muda mengenai Korea Selatan di Indonesia, khususnya pada Mahasiswa Hubungan Internasional FISIP Unjani?

\section{Tinjauan Pustaka}

Tinjauan pustaka yang digunakan dalam penelitian ini adalah penelitian yang berjudul Hallyu (Korean Wave) as Part of South Korea's Cultural Diplomacy and Its Impact on Cultural Hybridity in Indonesia oleh Teguh Puja Pramadya dan Jusmalia Oktaviani.. Penelitian ini menekankan pada konsep Cultural Hybridity dan Cultural 
Diplomacy sebagai salah satu faktor kesuksesan Korea Selatan dalam menyebarkan Gelombang Koreanya. Konsep Cultural Hybridity menjelaskan mengapa kebudayaan Korea Selatan mudah diterima oleh orang-orang di seluruh dunia, salah satunya karena ada perpaduan antara budaya tradisional Korea dengan budaya populer. Masyarakat Indonesia pun juga bisa dikatakan menerima masuknya budaya asing, dalam hal ini Gelombang Korea dalam kehidupan sehari-hari mereka. Temuan dalam penelitian ini memperkuat beberapa penelitian sebelumnya mengenai kuatnya pengaruh Gelombang Korea di dunia. Salah satu temuan dalam penelitian ini adalah, bagi responden yang mengisi kuisioner, Gelombang Korea cukup memberikan pengaruh bagi kehidupan sehari-hari mereka. Selain itu, penelitian ini juga memberikan saran pada pemerintah Korea Selatan atau pihak yang berwenang untuk tetap mengembangkan dan mempertahankan pencapaian Korea Selatan saat ini. Karena berkaca dari pengalaman Jepang dengan J-Pop-nya, budaya populer Jepang itu pun pudar seiring berjalannya waktu, jika popularitas budaya Korea Selatan ingin tetap terjaga, maka pemerintah harus mendukung inovasi bagi produk budaya Korea Selatan itu agar tetap eksis hingga beberapa waktu ke depan.

Penelitian kedua adalah Diplomasi Publik Korea Selatan Terhadap Indonesia: Pesona dan Tujuan Pencapaian oleh Angga Nurdin Rahmat. Penelitian ini berusaha menjawab apa saja instrumen diplomasi publik Korea Selatan yang menjadi daya tarik utama bagi sasarannya di Indonesia, dan sampai sejauh mana pencapaian tahapan diplomasi publik yang dijalankan oleh Korea Selatan di Indonesia. Data dalam penelitian ini dikumpulkan melalui teknik wawancara terhadap 100 responden dengan rentan usia 18-22 tahun yang berdomisili di Kota Bandung.

Berdasarkan hasil pembahasan yang dilakukan, peneliti menemukan bahwa tahapan pencapaian diplomasi publik dari Korea Selatan dengan menggunakan budaya populer di kalangan generasi muda Kota Bandung telah berhasil mencapai tahapan mempererat kedekatan. Hal ini dibuktikan dengan beberapa indikator yang telah ditanyakan kepada pada informan yang mana semua jawaban tersebut menunjukan bahwa Korea Selatan melalui budaya populer mampu membuat para informan yang mewakili generasi muda di Kota Bandung ingin semakin dekat dengan masyarakat di Korea Selatan melalui berbagai kegiatan baik terkait kunjungan pariwisata maupun tinggal untuk melanjutkan studi di negara tersebut.

Apabila para informan yang merupakan generasi muda ini ditempatkan sebagai pengambil kebijakan, maka kebijakan terhadap Korea Selatan akan sangat akomodatif. Hal ini merupakan harapan dari setiap negara, ketika semua negara akan bersifat akomodatif terhadap berbagai upaya pencapaian kepentingan negaranya. Oleh karena itu hasil yang perlu dicermati adalah apakah pengaruh tersebut akan tertanam dalam pikiran dan pandangan dari kalangan generasi muda tersebut, jika suatu saat mereka mendapatkan kesempatan untuk menjadi pengambil kebijakan di Indonesia.

Penelitian ketiga Budaya Kuliner sebagai Soft Power: Studi Perbandingan Thailand dan Republik Korea oleh Fazri Ramadhan, Teuku Rezasyah dan Windy Dermawan. Temuan dari penelitian menunjukkan bahwa soft power dalam kaitannya dengan diplomasi publik melalui kuliner sudah berhasil dilakukan oleh negara Thailand dan juga Korea Selatan. Hal ini tentu saja mempengaruhi juga persepsi kedua negara tersebut di mata penikmat budaya kulinernya. Penelitian ini berkontribusi memberikan sumbangsih menganai bagaimana penelitian mengenai diplomasi publik dilakukan oleh Korea Selatan dan juga oleh negara lain di Asia Tenggara yakni Thailand, melalui budaya kulinernya. Dalam beberapa bagian dari 
penelitian tersebut, dijelaskan bahwa gastrodiplomasi juga efektif untuk mengubah citra. Citra tersebut terlihat dari imej wisatawan yang melihat kedua negara, baik Thailand maupun Korea Selatan yang mampu menonjolkan kuliner sebagai salah satu citra positif dari negara. Jika penelitian terdahulu ini ingin melihat upaya-upaya diplomasi kuliner yang dilakukan dua negara serta citra yang dihasilkan pada wisatawan, maka penelitian ini ingin membahas pengaruh Gelombang Korea terhadap kaum muda di Indonesia.

Diikuti juga dengan Penelitian keempat yaitu Analysis of Samyang Instant Noodle's Market in Indonesia Using the Impact of Uncertainty Avoidance by Hofstede's Cultural Dimensions oleh Septyanto Galan Prakoso, Randhi Satria dan Nesya Cesari Kinanti. Hasil dari penelitian ini memberikan informasi terkait konsep uncertainty avoidance terhadap keputusan konsumsi pelanggan yang berasal dari masyarakat Indonesia. Penelitian ini juga memberikan gambaran mengenai kontribusi produk kuliner dengan popularitas Korean foods yang semakin mendunia diikuti dengan Gelombang Korea. Dalam penelitian ini, peneliti melihat bagaimana dampak dari suatu produk budaya Gelombang Korea, dalam hal ini secara khusus merek mi instan Samyang di masyarakat Indonesia. Hal ini menarik karena masyarakat Indonesia mayoritas muslim yang kebanyakan tidak makan daging babi, sementara seperti kita ketahui produk-produk kuliner Korea Selatan tentu tidak mengharuskan produknya berlogo halal. Di samping itu, masyarakat Indonesia juga mengkonsumsi mi instan dari produk lokal. Produk-produk mi instan dari Indonesia juga menguasai konsumsi mi instan. Penelitian ini berkontribusi dalam melihat bagaimana sebuah produk dari luar kemudian berusaha bersaing dan menarik hati masyarakat Indonesia. Hal ini sejalan dengan penelitian ini yang juga melihat bagaimana dampak Gelobang Korea pada responden yang merupakan mahasiswa di
HI Fisip Unjani, meskipun topiknya tidak hanya terbatas pada kuliner dari Korea saja, namun juga membahas hal-hal lain dalam Gelombang Korea.

\section{Metode Penelitian}

Metode penelitian yang digunakan adalah metode penelitian kualitatif. Penelitian kualitatif bermaksud untuk memahami fenomena-fenomena tentang apa yang dialami oleh subyek penelitian misalnya perilaku, persepsi, motivasi serta aktivitas (Moleong, 2006). Proses penelitian tersebut melibatkan upaya-upaya penting seperti mengajukan pertanyaan- dan prosedur, mengumpulkan data yang spesifik dari para partisipan, menganalisis data secara induktif mulai dari tema-tema yang khusus ke tema-tema yang umum, dan menafsirkan makna data (Cresswell, 2010).

Tipe penelitian yang digunakan dalam artikel ini adalah deskriptif analisis, yaitu suatu metode yang bertujuan untuk menggambarkan, mencatat, menganalisis dan menginterpretasikan kondisi-kondisi yang sedang terjadi atau ada. Dengan kata lain, penelitian deskriptif analisis bertujuan untuk memperoleh informasi-informasi mengenai keadaan saat ini, dan melihat hubungan antar variabel-variabel yang ada (Mardalis, 1995). Tipe penelitian deskriptif ini dipilih dalam penelitian ini karena merupakan jenis penelitian kualitatif, sehingga data yang dikumpulkan dalam penelitian ini sebagian besar data deskriptif dalam bentuk laporan dan uraian sehingga penelitian ini tidak mengutamakan angkaangka dan atau pengolahan data statistik, meskipun tidak menolak data kuantitatif.

Teknik pengumpulan data yang digunakan dalam penelitian ini adalah sebagai berikut: Observasi, dokumentasi dan focus group discussion (Sugiyono, 2014). Peneliti memilih pendekatan observasi karena peneliti berada pada lingkungan penelitian. Pendekatan dokumentasi juga dipilih dengan melakukan pengumpulan data-data sekunder yang bersumber pada literatur- 
literatur ilmiah, seperti buku, makalah, jurnal, majalah, surat kabar, dokumen resmi yang diterbitkan maupun tidak dari sumber-sumber lain yang dianggap relevan dengan kajian penelitian. Di akhir, peneliti melakukan FGD sebagai cara mengecek data primer langsung dan mendapatkan hasil diskusi yang produktif.

Teknik analisis data yang digunakan adalah analisis data secara kualitatif, yakni melalui (Sugiyono, 2014): Reduksi Data, yaitu memilih dan memilah data-data pokok yang sesuai dengan fokus penelitian; Penyajian data, yakni langkah menyajikan data dalam bentuk: kata-kata, kalimatkalimat, gambar, simbol, skema, bagan, grafik, tabel, dan matriks; Verifikasi Data, yaitu data yang telah terkumpul, diuji secara empiris sehingga validitas, realibitas dan obyektivitas data teruji.

Uji keabsahan data yang dilakukan dengan menggunakan uji kredibilitas dengan cara-cara berikut yaitu 1) Perpanjangan Pengamatan, Meningkatkan Ketekunan, 3) Triangulasi, 4) Analisis Negatif, 5) Member Check dan 5) Diskusi dengan teman sejawat (Sugiyono, 2014).

Triangulasi, yakni cross check atau pemeriksaan silang antara data, dengan tujuan untuk memperoleh kepercayaan dan akurasi data. Triangulasi dilakukan dengan mempertimbangkan aspek sumber, teknik dan waktu. Sementara Analisis negatif, yakni memeriksa adanya narasumber yang menjawab atau menanggapi pertanyaan secara berbeda dengan sebagian besar responden lainnya sehingga perlu ditelusuri motif dan alasannya.

Lalu, Member Check, yakni meminta dan mengkonfirmasi kepada narasumber atau informan untuk melihat dan membaca kembali rangkuman hasil dari pembahasan yang dilakukan peneliti sehingga informan dapat memberikan persetujuan terhadap isi dari pembahasan tersebut. Diskusi dengan Teman Sejawat. Dalam penelitian ini peneliti menunjuk dua narasumber untuk berdiskusi (Sugiyono, 2014).
Dari beberapa metode tersebut, peneliti terutama menggunakan Observasi (karena peneliti bisa mengamati secara langsung) dan Focus Group Discussion sebagai cara peneliti mengambil atau mengumpulkan data. Agar keabsahan data teruji, peneliti melakukan perpanjangan pengamatan dan ketekunan mengingat dalam metode kualitatif, peneliti adalah human instrument. Sementara itu analisis negatif, triangulasi dan diskusi dengan teman sejawat terutama dilakukan saat FGD berlangsung bersama 13 mahasiswa yang menyukai budaya Korea dan 2 narasumber dari Ilmu HI dan kajian budaya yang telah peneliti tunjuk, berdasarkan pada butirbutir pertanyaan yang telah peneliti susun. Pertanyaan bersifat terbuka atau openended questions karena menanyakan opini, bukan sekedar jawaban Ya atau Tidak.

\section{HASIL DAN PEMBAHASAN}

Seiring berjalannya waktu, menjadi normal dan juga tak terhindarkan bagi sebuah masyarakat untuk kemudian menikmati budaya lain, terutama apabila budaya tersebut hadir dalam bentuk produk budaya populer. Hal ini muncul terutama dari persinggungan yang dikenal dengan globalisasi, sebuah istilah yang sudah lazim menjelaskan interaksi di mana dunia menjadi satu dan seolah-olah tanpa batas (Shim, 2006: 26). Dengan adanya globalisasi, produk budaya populer dari negara lain dapat menembus batas-batas geografis sehingga cakupannya menjadi sangat besar. Audiensnya tidak lagi dalam batas nasional, namun bisa menjangkau skala internasional.

Korean Wave atau Hallyu pun juga berada dalam posisi yang diuntungkan dengan adanya globalisasi, karena industri hiburan di Korea Selatan ternyata bisa dengan mudah masuk dan kemudian dikonsumsi dengan masif di negara-negara lain, salah satunya adalah negara Indonesia. Peran media, baik media massa dan media elektronik, memberikan jalan yang besar terhadap fenomena ini (June dan Dukut, 
2012: 196; Valentina dan Istriyani, 2013: 74), hal ini dapat dilihat dari mudahnya anak-anak muda Indonesia mengakses informasi terhadap segala sesuatu yang berbau Korea, dimulai dari pemilihan gaya fashion dan juga produk-produk budaya lainnya, seperti musik dan drama.

Kecenderungan trend pun juga berubah seiring dengan aktor yang bermain dalam kontestasinya. Bila awalnya kita mengenal globalisasi dengan mayoritas produk budaya barat yang didominasi oleh budaya Amerika; dua dekade terakhir memunculkan gaya globalisasi baru. Globalisasi yang muncul dan menguat dari kawasan Asia.

Apabila sebelumnya di kurun waktu 1970-1990an ada dominasi Cool Japan (Valentina dan Istriyani, 2013: 74), dua dekade terakhir memunculkan pemain baru yaitu Korea Selatan. Korea Selatan membawa angin baru yang kemudian kita kenali dengan Korean Wave/Hallyu atau Gelombang Korea. Perubahan kontestasi ini masih berlangsung hingga hari ini. Gelombang Korea berhasil menancapkan pengaruhnya di berbagai negara karena Gelombang Korea tidaklah berjalan sendiri. Perkembangan pesatnya mendapat dukungan penuh dari pemerintah dan juga medianya. Semua aktor saling bekerja sama dan memastikan bahwa efek adiksinya tetap terjaga dengan memastikan kualitas dan memproduksi produk-produk budayanya dengan kuantitas yang besar dan menjangkau semua kalangan, "tanpa diskriminasi" apa pun (Valentina dan Istriyani, 2013: 74).

Dalam rentang dua dekade terakhir, industri kreatif di Korea Selatan menjadi sangat berkembang, karena pemerintah pun mendorong kerjasama antar industri di negara mereka agar bisa bergerak maju dan berkompetisi di pasar global (Hennida, 2013: 121). Penggunaan kebijakan ekspor menjadi pilihan, terutama karena hal ini meningkatkan kesempatan pemerintah Korea Selatan agar mendapatkan manfaat yang lebih besar untuk perekonomian mereka. Perkembangan industri kreatif dan juga manufaktur dari Korea Selatan berjalan dengan lancar terutama karena produk yang mereka produksi, dibuat dengan memastikan standar dan kualitas yang dapat diterima dengan luas oleh masyarakat di berbagai tempat di dunia (Hennida, 2013:121). Penyebaran produk yang mereka produksi pun didukung dengan penggunaan media-media alternatif yang juga mulai ramai dipergunakan oleh semua level masyarakat. Penggunaan sosial media memberi kesempatan yang lebih besar lagi dalam membangun komunikasi yang intens antara para idol dan para penggemarnya.

Hal ini juga yang memberikan kontribusi besar terhadap pemasaran barang-barang busana dan juga gawai dari Korea Selatan. Pemasaran yang mereka lakukan didukung dengan dekatnya sosok idol di tengah para penggemarnya, sehingga gaya hidup dan juga gaya budaya mereka menjadi mudah untuk diduplikasi oleh para penggemarnya. Produk kreatif dari budaya populer Korea Selatan memang menjadi pilihan karena format dan juga nilai yang ditampilkan oleh mereka masih dianggap dekat dengan budaya yang ada di Asia. Sehingga, kebanyakan penikmatnya tidak merasa asing dan terkejut dengan cerita yang ada pada drama-drama yang mereka tonton. Kisah romantis seolah menjadi magnet yang dengan mudah masuk ke dalam setiap lapisan masyarakat penikmatnya. Batasan usia tidak menjadi halangan, karena nilai-nilai universalnya masih tetap ditonjolkan secara berkala (Ardia, 2014: 14-16).

Di sisi lain, hal ini pun perlu diperhatikan secara seksama, karena bagaimana pun budaya populer dari Korea Selatan, tetap juga memiliki tujuan dan signifikansinya tersendiri. Sehingga, perananan media dan pemerintah yang menyokongnya tetap harus dilihat secara kritis. Pendistribusian budaya populer tidak berhenti di sana, Diplomasi Publik Korea Selatan secara tidak langsung sedang 
berjalan dengan sangat cair dan tidak terbendung. Bagaimana pun, kesuksesan produk kreatif dari budaya populer selalu diiringi dengan distribusi yang masif; sehingga apabila kemudian produk-produk tersebut menjadi raja dan menguasai pasar di negara-negara penikmatnya, hal itu tentu saja merupakan konsekuensi logis karena kita membiarkan penerimaan itu secara sadar terhadap produk budaya Korea Selatan.

Dalam Hubungan Internasional, dikenal beberapa teori yang bisa menjelaskan bagaimana budaya juga mempunyai peran yang sangat penting. Gelombang Korea yang mendunia pun dijelaskan dengan teori-teori seperti soft power, nation-branding, serta diplomasi publik. Nye (2003 dalam Wang 2007:9), menjelaskan mengenai soft power sebagai "the ability to get what you want by attracting and persuading others to adopt your goals". Joseph Nye Jr. menyatakan bahwa soft power merupakan aspek yang digunakan untuk mempengaruhi orang meskipun ia berada di tempat yang jauh sekalipun, tanpa harus memaksa orang tersebut.

Negara yang mampu menggunakan soft power nya dengan baik akan mudah memenangkan hati banyak orang, terutama di era informasi seperti ini. Menurut Jan Mellisen, Nation-branding mencakup tiga area yakni: brand export, foreign direct investment, dan tourism. Menurut Mellisen (2005), budaya punya kaitan erat dengan diplomasi publik, sehingga diplomasi publik bukan hanya fokus pada bagaimana pemerintah menyampaikan pesan tapi juga bagaimana relasi secara kultural dibangun dengan aktor non-pemerintah (masyarakat sipil) di luar negeri:

"Cultural exchange is not only 'art' and 'culture' but also communicating a country's thinking, research, journalism and national debate... The new public diplomacy is no longer confined to messaging, promotion campaigns, or even direct governmental contacts with foreign publics serving foreign policy purposes. It is also about building relationships with civil society actors in other countries and about facilitating networks between non-governmental parties at home and abroad... Cultural relations represent the non-governmental voice in transnational relations."

Amelia Arsenault (2009) menyatakan bahwa hal yang mempengaruhi diplomasi publik salah satunya adalah bagaimana diplomasi publik tersebut didistribusikan dan dikonsumsi oleh masyarakat. Selain itu, bagaimana perkembangan teknologi membantu menyebarkan bentuk diplomasi publik ini. Dalam dekade terakhir, dunia menyaksikan popularitas Gelombang Korea yang berasal dari Korea Selatan. Budaya populer ini merambah ke berbagai produk budaya asal negeri ginseng tersebut, yakni musik, drama, kuliner, film, variety show, industri kecantikan, fashion, dan sebagainya.

Sebelum adanya K-Pop, sebetulnya dunia telah lebih dulu mengenal J-Pop yang berasal dari Jepang. J-Pop sempat populer dan secara masif menyebarkan produkproduk budayanya di berbagai media. Namun saat ini seiring berjalannya waktu JPop mulai meredup dan tenggelam bahkan hingga digantikan oleh meledaknya popularitas K-Pop. Peneliti beranggapan bahwa Korea Selatan termasuk beruntung karena Gelombang Korea lahir dengan berkembang pesatnya teknologi informasi yakni di masa internet sedang pesat. Distribusi yang begitu masif melampaui batas-batas negara dengan media internet sangat signifikan terhadap booming-nya Gelombang Korea tersebut. Dengan bantuan sosial media, Gelombang Korea menjadi mudah dijangkau oleh siapapun selama seseorang terhubung dengan koneksi internet.

Korea Selatan sendiri merupakan salah satu negara dengan ekonomi terbesar dunia dari benua Asia. Kemajuan industri 
serta teknologi tinggi yang pesat membuat Korea Selatan menjadi anggota Organization for Economic Co-operation and Development (OECD) dan G20, bahkan di OECD Korea Selatan termasuk negara dengan kemajuan tercepat di dunia. Industri negaranya bergantung pada elektronik, telekomunikasi, otomotif, dan kimia. Pada tahun 2018, GDP per kapita mencapai 40.112 USD (Global Edge, 2019). Perkembangan kapasitas tersebut tentu membuat pergerakan pemerintah Korea Selatan untuk mendorong industri K-pop sebagai sarana diplomasi.

Park Gil-sung (2013), menyatakan bahwa Korea Selatan dahulu seringkali diasosiasikan dengan kemiskinan, Perang Korea, dan tempat buruh industri. Namun, semenjak adanya Gelombang Korea, orangorang mulai mengubah persepsinya sehingga Korea Selatan sekarang sama dengan negara dengan kebudayaan pop, kuliner, serta produk-produknya yang luar biasa. Faktanya, banyak orang yang mempelajari bahasa Korea, sebagai inti dari kebudayaan atau bisa dikatakan sebagai bentuk ketertarikan terhadap budaya Korea, bukan untuk kepentingan bisnis tapi untuk kepentingan pribadi mereka. Tentu ini menjadi peluang besar bagi Korea Selatan untuk terus mengembangkan pengaruh mereka dalam tatanan internasional.

Tercatat pada tahun 2016 pendapatan K-pop dari pasar global mencapai angka 4,7 juta USD atau jika dirupiahkan menjadi 66,8 triliun. Pencapaian tersebut berhasil membukukan rekor tersendiri bagi pemerintahan Korea Selatan. Catatan pendapatan tersebut telah berhasil memberi stimulus luar biasa untuk perekonomian Korea Selatan. Indikator yang paling jelas dapat dilihat dari kenaikan ekspor komoditas budaya dan konsumen yang mencapai sekitar $2 \%$ dari total pertumbuhan ekspor negara tersebut. Hal ini tentu menunjukan efektifitas dari penggunaan soft power mereka melalui Gelombang Korea, yang pada akhirnya membantu industri kreatif yang mereka miliki terus berkembang dan membuka akses pasar yang lebih luas.

K-Pop memiliki keunggulan dari banyak aspek meliputi pengaturan musik yang bisa dianggap matang, penggarapan liriknya yang menarik, kecenderungan untuk menonjolkan sisi personal yang nyentrik, kostum yang mencolok, dan juga koreografi yang cantik. Faktor - faktor tersebut membuat kebudayaan tersebut dapat dengan cepat bertumbuh dan mempengaruhi pihak lain yang menjadi pengguna atau penikmat dari produkproduk yang mengusung kombinasi dari kebudayaan Korea Selatan dan budaya populer lainnya tersebut.

Kesuksesan K-Pop ini terjadi karena pemerintah berhasil secara efektif menerapkan sistem perekonomian yang berdasar pada pengembangan sesuai dengan teori pertumbuhan makroekonomi. Dalam mendukung perkembangan K-Pop. Industri musik di Korea Selatan mencatatkan pertumbuhan signifikan, hal ini tentu tidak lepas dari peran pemerintah yang maksimal dan konsisten dalam rangka mengembangkan tiga hal penting yang menjadi titik berat dari teori tersebut, yaitu: sumber daya penunjang, sumber daya manusia, dan teknologi. Peran pemerintah Korea Selatan salah satunya dapat terlihat dari keseriusan mereka dalam memilih, menentukan, dan melibatkan sumber daya manusia dalam hal ini aktor-aktor yang akan digunakan sebagai instrumen diplomasi mereka.

Secara historis, pasca periode krisis moneter yang melanda Asia di tahun 1998, pemimpin Korea Selatan mengambil langkah strategis dengan melibatkan penggunaan soft power yang dimiliki negaranya yaitu musik. Hal ini dilakukan dalam rangka membangun citra positif dan memperkuat aspek kultural yang dimiliki oleh negara tersebut menjadi keputusan yang amat penting sehingga mendorong Korea Selatan sebagai negara yang unggul dalam aspek budaya populer yang dimiliki. 
Pemerintah Korea Selatan mengalokasikan jutaan dolar untuk membentuk kementerian kebudayaan yang bahkan memiliki satu departemen khusus yang diperuntukan bagi pengembangan K-Pop, Keseriusan pemerintah Korea Selatan terlihat dengan jelas dari dipersiapkannya badan khusus tersebut. Maka tidak mengherankan apabila K-Pop mampu untuk terus mengalami perkembangan secara signifikan.

Sebagai perbandingan dan contoh, terdapat satu daerah di Seoul yang ditetapkan sebagai pusat dari pengembangan industri K-Pop, adapun daerah tersebut ialah Chang-dong. Di daerah ini terdapat banyak gedung-gedung yang dapat dimanfaatkan sebagai venue dari konser. Selain itu, di daerah ini terdapat juga studio rekaman, galeri seni, restoran, dan toko ritel yang menjual berbagai macam aksesoris dan perlengkapan yang berhubungan dengan $\mathrm{K}$ Pop. Sudah jelas bahwa agenda pemerintahan dalam pembangunan distrik tersebut ialah untuk menopang tumbuh dan berkembangnya budaya K-Pop dengan mendorong aspek sumber daya penunjang seperti yang diutarakan dalam teori pertumbuhan makroekonomi. Seoul Arena dapat dianggap sebagai ambisi terbesar yang diimplementasikna oleh pemerintah Korea Selatan, Pembangunan gedung pertunjukan tersebut terus berlangsung dan diproyeksikan selesai pada tahun 2020. Gedung ini akan menjadi gedung pertunjukan seni terbesar di Korea Selatan dengan kapasitas tempat duduk mencapai 20.000 orang.

Dalam pengembangan aspek pengembangan sumber daya manusia, pemerintah mendorong pula tiga perusahaan rekaman/ label besar yaitu: SM, YG, dan JYP Entertainment untuk dapat terus menggali potensi dan bakat yang dimilliki oleh para idola K-Pop yang bernaung dibawah label tersebut. Bakatbakat ini dipersiapkan dengan sangat matang dan memang secara khusus dicetak sebagai pion yang dapat menarik animo masyarakat dan merepresentasikan identitas Korea Selatan, jelas secara keseluruhan proses tersebut tidak memakan waktu yang singkat. Dibutuhkan setidaknya beberapa tahun persiapan sebelum mereka dibiarkan memulai karir mereka di industri musik. Menariknya pelatihan yang diberikan tersebut tidak hanya berfokus pada kemampuan menyanyi atau menari yang digunakan mereka untuk masuk ke dunia hiburan, pemerintahan Korea Selatan juga menetapkan bahwa penguasaan bahasa asing dan komunikasi publik menjadi salah satu keahlian yang harus dimiliki oleh para idola K-Pop (Soesmanto, 2018).

Persiapan tersebutlah yang pada akhirnya berhasil menciptakan demam KPop yang mendunia. Persiapan dalam mengedukasi dan menyiapkan para artis idola yang menjadi bagian dari K-Pop, membuat kendala yang ada seperti bahasa tidak lagi menjadi penghalang yang berarti dalam interaksinya dengan para penggemar yang berasal dari mancanegara. Begitupun ketertarikan dari para penggemar K-Pop terhadap bahasa Korea Selatan membuat lagu-lagu K-Pop yang berbahasa Korea juga tetap dapat dinikmati. Sebagai efek domino, fenomena popularitas budaya tersebut juga memberikan pengaruh signifikan dalam menaikkan pamor produk-produk Korea Selatan. Pengaruh K-Pop berdampak positif untuk industri Korea Selatan lainnya seperti industri pariwisata dan manufaktur (Soesmanto, 2018).

Hingga saat ini K-Pop telah menunjukan keberhasilan yang tinggi dalam kiprahnya di pangsa pasar musik yang mengedepankan lagu dan tari. Sebenarnya, segmen pasar tersebut sebelumnya lebih didominasi oleh industri musik Amerika Serikat yang telah populer semenjak era Michael Jackson dan boy-band di tahun 1990-an. Kemampuan Korea Selatan dalam menggabungkan lagu-lagu dengan lirik yang baik, musik yang bagus dan juga gerakan tarian yang menarik untuk 
diperagakan tentu menjadi kunci dari keberhasilan mereka. Fenomena menarik muncul juga dari aspek penjualan produk, ketika di negara lain penjualan album musik dalam bentuk CD mengalami penurunan dan mulai ditinggalkan. Album musik dan CD K-pop justru laris di pasaran. Di tahun 2012 saja tercatat pangsa pasar CD K-pop mengalami pertumbuhan mencapai $11 \%$. Dan jika ditotal penjualan dari produk tersebut menyumbang pemasukan besar bagi Industri K-pop bahkan menjadi sumber pendapatan mayoritas dengan sumbangan mencapai $74 \%$ dari total pemasukan yang diperoleh industri tersebut (Soesmanto, 2018).

Dari penelitian yang dilakukan oleh Universitas London, diperkirakan bahwa Korea Selatan mendapat 5 kali lipat dari setiap dolar yang mereka investasikan dalam pengembangan K-pop. Hal ini menjadi mungkin karena dari apa yang dihasilkan dari industri hiburan mereka memberikan pengaruh yang besar terhadap penjualan produk Korea Selatan yang lain seperti ponsel atau televisi. Samsung dan LG dapat dijadikan sebagai contoh merek nasional yang mendunia sebagai dampak dari penyebaran konten musik, video, maupun perfilman Korea Selatan (Soesmanto, 2018).

Dari agenda Focus Group Discussion (FGD) yang dilakukan oleh peneliti, terdapat beberapa jawaban dan penjelasan dari responden sebagi berikut: Secara umum, sebagian besar responden mengenal kebudayaan Korea sejak memasuki usia remaja. Maraknya tayangan-tayangan yang berhubungan dengan Korea yang ditayangkan oleh media di dalam negeri juga mampu menarik perhatian para penontonnya untuk mencari tahu lebih jauh mengenai kebudayaan Korea. Menurut pendapat mereka, selain memiliki kualitas yang baik, produk budaya Korea Selatan yang mereka tonton dan juga nikmati memberikan dampak baik secara psikologis. Sebagian responden menyampaikan ketertarikan mereka terhadap bahasa asing menjadi bertambah seiring kecintaan mereka saat mendengarkan musik atau menonton drama favorit mereka.

Seperti yang sudah disinggung sebelumnya, keinginan belajar bahasa asing, seperti bahasa Korea akhirnya menjadi salah satu keinginan para peserta responden. Hal tersebut terlihat dari upaya mereka untuk belajar bahasa Korea baik secara formal dan informal di berbagai kesempatan yang mereka miliki. Namun demikian, meskipun mereka menggemari budaya Korea, hal ini tidak serta merta menjadikan mereka tertarik untuk bekerja di negara tersebut. Peneliti berasumsi bahwa kecenderungan ini terjadi karena responden merupakan mahasiswa dalam jurusan Hubungan Internasional yang sudah tentu mengenal kebijakan-kebijakan yang diambil oleh Korea Selatan terkait dunia kerja. Usia yang semakin dewasa juga mempengaruhi pemikiran para responden untuk lebih rasional dalam menyikapi Kebudayaan Korea ini.

Dari apa yang disampaikan oleh responden sepanjang FGD, diketahui bahwa para penggemar budaya Korea Selatan ini seringkali mengikuti trend di berbagai bidang (tidak terbatasi di hanya musik atau drama misalnya). Selain itu, mereka juga kemudian mulai tertarik untuk menggunakan atau mencontoh gaya berbusana dan menggunakan kosmetik yang marak dan populer di Korea Selatan.

Budaya Korea telah membuat para penggemarnya bukan hanya mengikuti perkembangan yang ada dalam segi hiburan, namun budaya Korea juga mampu membentuk kebiasaan bagi para penggemarnya untuk juga mengkonsumsi produk-produk yang dikeluarkan oleh mereka. Budaya Korea dapat dianggap bukan hanya efektif untuk meraih penggemar namun juga berhasil menempatkan penggemar tersebut menjadi konsumen dari produk mereka. Mengikuti budaya Korea memberikan banyak manfaat bagi kehidupan responden. Selain sebagai 
sarana belajar dan pertukaran budaya melalui bahasa dan pemahaman terhadap negara Korea, budaya Korea juga secara tidak langsung mampu menciptakan citra yang kuat sehingga dapat mengubah cara pandang para penggemarnya; salah satunya mengubah pandangan mereka terhadap standar kecantikan.

Tingkat keberhasilan diplomasi publik yang dilakukan Korea Selatan melalui Gelombang Korea amatlah tinggi. Melalui diplomasi ini mereka berhasil membuat orang yang sebelumnya awam dan sama sekali tidak mengetahui mengenai negara mereka menjadi lebih mengetahui budaya dan kehidupan yang ada di negara tersebut, yang menjadikan hal ini lebih baik adalah proses pengenalan yang diberikan melalui media hiburan yang mereka buat dapat membuat para penontonnya penasaran dan melakukan riset mengenai negara mereka.

Dari hasil diskusi selama proses FGD, sebagian besar responden menjawab belum pernah mendatangi konser (hanya ada satu responden yang pernah datang pada beberapa konser). Meskipun demikian, responden juga mengatakan bahwa mereka masih tetap mengikuti kabar-kabar terbaru mereka melalui sosial media seperti Instagram dan Youtube, dan juga mengikuti perkembangan artis dan musisi favorit mereka melalui tontonan seperti drama dan variety show dari layanan Over-The-Top (disingkat OTT) yang menayangkan judul-judul film dan serial dari Korea.

Terkait pariwisata, apabila memiliki uang dan kesempatan, mayoritas responden menjawab memilih Seoul sebagai pilihan destinasi mereka. Hal ini menunjukan bahwa ibukota dari Korea Selatan masih menjadi destinasi favorit bagi para penggemarnya, terlepas dari banyaknya wilayah lain yang digunakan sebagai latar atau tempat pengambilan gambar dari drama-drama yang diproduksi oleh Korea Selatan.
Sedangkan terkait pengetahuan responden terhadap bentuk pemerintahan Korea yang lebih spesifik ternyata tidak sepenuhnya dapat dijawab oleh sebagian besar responden. Hal ini menunjukan bahwa Korean Wave memang murni bertujuan untuk membentuk pemahaman positif terhadap Korea Selatan terbatas hanya dalam bidang entertainment. Meskipun diplomasi sendiri merupakan bagian dari politik namun dalam melakukan diplomasi budaya ini terlihat bahwa Korea memilih menggambarkan Sebagian saja kebijakan-kebijakan mereka yang berdampak positif bagi masyarakatnya seperti wajib militer dan apresiasi terhadap seniman di negara tersebut. Hal-hal berkaitan dengan wajib militer diketahui dengan baik oleh peserta karena sering muncul dalam drama dan musik Korea.

Tanggapan positif responden menunjukan bahwa meskipun Gelombang Korea merupakan sebuah upaya diplomasi dari Korea Selatan, mayoritas responden menganggap bahwa cara ini adalah cara yang efektif dan responden berharap bahwa akan dapat terjalin lebih banyak kerjasama antara Indonesia dan Korea Selatan. Dari jawaban yang diberikan terlihat jelas bahwa responden masih meyakini bahwa pengaruh dari Budaya Korea masih dalam taraf normal dan bentuk kebijakan pembatasan yang bermaksud untuk memproteksi budaya lokal merupakan hal yang bukan suatu urgensi.

Dampak dari tersebarnya budaya Korea Selatan di Indonesia tidak memberikan efek domino yang buruk. Responden justru mendapatkan banyak dampak positif yang didapat dari mengikuti perkembangan Gelombang Korea diantaranya adalah membantu mereka dalam proses bersosialisasi dan berinteraksi dengan penggemar budaya Korea lainnya, bahkan juga yang berasal dari luar negeri. Responden juga mengatakan bahwa seringkali mereka mengidentifikasikan diri mereka dengan girlband atau boyband tertentu dan 
berjejaring dengan komunitas fanbase yang sama. Hal ini membantu mereka untuk mendapatkan informasi yang terbaru dari waktu ke waktu.

Konsistensi dan keseriusan dalam mempersiapkan diplomasi budaya dapat dianggap sebagai kunci dari keberhasilan diplomasi budaya yang dilakukan oleh Korea Selatan melalui Gelombang Korea. Selain itu variasi yang baik dalam penciptaan karya seni dalam karya-karya seniman mereka juga dianggap sebagai faktor vital dalam pengembangan Gelombang Korea. Sinergisitas antara pemerintah dan masyarakat Korea juga menjadi salah satu aspek yang dianggap oleh responden menjadi kunci keberhasilan Gelombang Korea hal ini tentu menjadi pengetahuan dan cerminan baik dari Korea Selatan yang berhasil ditanamkan kepada orang-orang yang mengikuti trend yang mereka buat.

Variasi dan pilihan beragam yang ditawarkan oleh Korea menjadi faktor yang dianggap sebagai alasan utama pembeda antara trend Gelombang Korea dengan budaya lokal Indonesia. Anggapan bahwa kondisi dunia hiburan Indonesia yang kurang baik tentu menjadi suatu jawaban yang perlu dijadikan sebagai pertimbangan untuk melakukan perombakan dalam dunia hiburan Indoensia saat ini. Selain sebagai bentuk pengembangan dari hal tersebut, tentu perkembangan dalam dunia hiburan juga akan memastikan bahwa kaum muda Indonesia khususnya yang telah mengikuti budaya lain dapat pula mulai memberi apresiasi besar terhadap karya seniman Indonesia.

Mayoritas responden yang menganggap bahwa budaya Indonesia akan mengalami kesulitan untuk dikembangkan tentu merupakan pernyataan yang miris karena terlontar dari kaum muda yang seharusnya menjadi pelopor dari perkembangan budaya lokal. Maraknya penjualan dari produk bajakan memang juga menjadi suatu penyakit masyarakat yang kurang mengapresiasi nilai seni dari karya buatan lokal maupun mancanegara. Pemerintah sudah seharusnya menerapkan regulasi baru yang memproteksi karyakarya seniman lokal agar dapat membuat budaya Indonesia semakin berkembang karena memang sesuai pernyataan salah satu responden dunia hiburan saat ini dapat memberikan potensi besar terhadap perkembangan ekonomi nasional.

Jawaban yang beragam dari responden menunjukan bahwa terdapat banyak platform yang dapat digunakan untuk tetap terhubung dengan perkembangan budaya Korea. Platform berbayar maupun yang tidak berbayar memungkinkan mereka untuk selalu up to date dengan perkembangan yang terjadi dalam dunia hiburan Korea. Hal ini tentu bisa dijadikan pertimbangan oleh pemerintah Indonesia untuk mendukung seniman lokal agar karya-karya mereka dapat didistribusikan melalui berbagai platform dengan tujuan untuk menjaga kelestarian budaya Indonesia dan memastikan bahwa budaya Indonesia terus dapat bersaing seiring perkembangan jaman yang terjadi.

\section{KESIMPULAN}

Salah satu faktor yang mendorong keberhasilan Gelombang Korea yakni kemunculannya di saat yang tepat, yang bertepatan dengan kemajuan teknologi komunikasi informasi yakni internet sedang berkembang dengan pesat. Hal tersebut membantu kebudayaan Korea ini mencapai masyarakat yang lebih luas, dibanding saat kemunculan Jpop. Hiburan yang dikemas dengan profesionalitas, konsistensi, dan juga dengan diiringi dukungan besar dari pemerintah Korea Selatan, membuat kemajuan industri hiburan di Korea Selatan menjadi teramat signifikan.

Indonesia perlu belajar banyak untuk mengemas hiburan yang bersifat profesional, agar penonton tertarik sehingga tidak harus menonton industri hiburan dari luar negaranya. Indonesia juga 
harus berani melirik Hak Kekayaan Intelektual sebagai salah satu pendapatan negara, seperti yang dilakukan AS dengan Hollywood, India dengan Bollywood, dan seterusnya. HaKI sangat potensial untuk menjadi salah satu sumber pendapatan negara yang mampu mendatangkan banyak manfaat secara langsung pada masyarakat, bahkan punya efek domino pada sektor lain, misalnya pariwisata.

Melalui penelitin ini, penulis melihat bahwa ada kemungkinan dan kesempatan

\section{DAFTAR PUSTAKA}

\section{Buku}

Arsenault, A. (2009). Public Diplomacy 2.0. In Toward a New Public Diplomacy (pp. 135-153). Palgrave Macmillan, New York.

Creswell, J. W. (2010). Research design pendekatan kualitatif, kuantitatif, dan mixed. Yogyakarta: Pustaka Pelajar.

Mardalis. (1995). Model Penelitian Suatu Pendekatan Proposal. Jakarta: Bumi Aksara.

Melissen, J. (Ed.). (2005). The new public diplomacy (pp. 292-31). Basingstoke: Palgrave Macmillan.

Moleong, L.J. (2006). Metode Penelitian Kualitatif, edisi Revisi, Bandung.

Sugiyono (2014). Metode Penelitian Kuantitatif, Kualitatif, dan R\&D. Bandung: Alfabeta.

\section{Jurnal}

Ardia, V. (2014). Drama Korea dan Budaya Popular. LONTAR: Jurnal IImu Komunikasi, 2(3), 12-18.

Hennida, C. (2013). Corporate strategies in the spread of hallyu (korean wave) in indonesia. MOZAIK HUMANIORA, 13(2), 117-125.

Jang, G., \& Paik, W. K. (2012). Korean Wave as tool for Korea's new cultural diplomacy. Advances in Applied Sociology, 2(03), 196-202.

June, S., \& Dukut, E. M. (2012). THE POPULARITY OF KOREAN MUSIC (K- untuk penelitian lanjutan. Penelitian selanjutnya bisa membahas mengenai pengaruh Gelombang Korea terhadap pariwisata, baik peningkatan jumlah wisatawan ataupun indikator lainnya. Bisa pula membahas mengenai pengaruh Gelombang Korea pada daerah lain di Indonesia. Penelitian yang berfokus pada Indonesia juga bisa dilaksanakan, yakni bagaimana pemerintah mendorong HaKI untuk dijadikan pendapatan negara.

POP) AMONG PERANAKAN CMNESE UNDERGRADUATE STUDENTS OF SOEGIJAPRANATA CATHOLIC UNIVERSITY. Celt: A Journal of Culture, English Language Teaching \& Literature, 12(2), 193-204.

Prakoso, S. G., Satria, R., Kinanti, N. C., \& Puspitasari, R. (2019). Analysis of Samyang Instant Noodle's Market in Indonesia Using The Impact of Uncertainty Avoidance by Hofstede's Cultural Dimensions. Insignia: Journal of International Relations, 6(2), 123136.

Pramadya, T. P., \& Oktaviani, J. (2016). Hallyu (Korean Wave) as Part of South Korea's Cultural Diplomacy and Its Impact on Cultural Hybridity in Indonesia. Jurnal Dinamika Global, 1(01), 87-116.

Rahmat, A. N. (2018). DIPLOMASI PUBLIK KOREA SELATAN TERHADAP INDONESIA. Jurnal Dinamika Global, 3(01), 68-93.

Ramadhan, F., Rezasyah, T., \& Dermawan, W. (2019). Budaya Kuliner sebagai Soft Power: Studi Perbandingan Thailand dan Korea Selatan. Insignia: Journal of International Relations, 6(2), 137-153.

Valentina, A., \& Istriyani, R. (2013). Gelombang Globalisasi ala Korea Selatan. Jurnal Pemikiran Sosiologi, 2(2), 71-86. 


\section{Internet}

Arradian, D. (2021). Berkat Drama Korea,

Viu Klaim Jadi Layanan Streaming Terbesar di Asia Tenggara. SINDOnews.com. diakses dari https://tekno.sindonews.com/read/3 64692/207/berkat-drama-korea-viuklaim-jadi-layanan-streamingterbesar-di-asia-tenggara1615781033.

Soesmanto, Tommy. (2018, 7 Desember)._Kpopnomics: Bagaimana Indonesia dan negara lain bisa belajar dari industri musik Korea?. The Conversation. Diakses dari http://theconversation.com/kpopnomics-bagaimana-indonesiadan-negara-lain-bisa-belajar-dariindustri-musik-korea-107897.

\section{Hasil Wawancara}

Pramadya, T. P., \& Oktaviani, J. (2019, 13 September). Focus Group Discussion (FGD). Dilaksanakan di Laboratorium Hubungan Internasional, FISIP, Universitas Jenderal Achmad Yani. 